\title{
Comparative Study of Different Soil Parameters Using Blending Technology
}

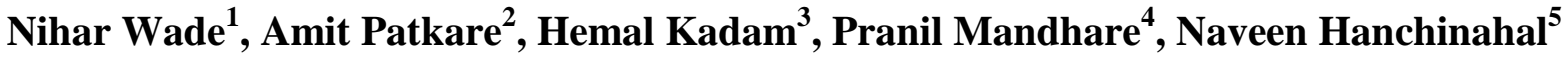 \\ ${ }^{1234}$ UG Students, Department of Civil Engineering, St John College of Engineering \& Management, Palghar \\ ${ }^{5}$ Associate Professor, Department of Civil Engineering, St John College of Engineering \& Management, Palghar
}

Received on: 04 May, 2021, Revised on: 30 May, 2021, $\quad$ Published on: 1 June, 2021

\begin{abstract}
The soil is the only material which supports the structural foundation of buildings, dams and roads. In About one third of Indian areas are covered with black cotton soil, which occurs in western and central parts of India. Many areas are covered with silt and clay soils as these possess poor bearing capacity problems during the construction or during the life service of structures. For the poor engineering properties of these soils, it has forced Engineers to improve the bearing capacity problem by improving the engineering properties of soil by using different soil stabilization methods. Black Cotton soil is one which when associated with as engineering structure and in presence of water will show a tendency to swell or shrink causing the structure to experience moments which are largely unrelated to the direct effect of loading by the structure. Black cotton soil is not suitable for the construction work on account of its volumetric changes. It swells and shrinks excessively with change of water content. Such tendency of soil is due to the presence of fine clay particles which swell, when they come in contact with water, resulting in alternate swelling and shrinking of soil due to which differential settlement of structure takes place, but as we all know that red soil has low swelling and shrinkage properties and high load bearing capacity also. so, to stabilize black cotton soil here we use red soil to overcome the properties of black cotton soil and to increase the load bearing capacity of soil.
\end{abstract}

Keywords-Blending, Black cotton soil, red soil.

\section{I- INTRODUCTION}

T hese methods of soil stabilization involve of replacing of soil or using complex methods of chemical stabilization. The clay of medium to high compressibility characterized by high swelling and shrinkage properties which covers the area of west Maharashtra regions has become a challenge to the engineers in construction. This soil when becomes dry is very hard but loses its strength properties completely when it is in wet condition. Therefore, it is very important to know various properties of soil such as physical and engineering properties. Soil can be stabilized by chemically or mechanically. The chemical stabilizers are the substances that can enter in the natural reactions of the soil and control the moisture which is getting into the clay particles. These methods of soil stabilization involve of replacing of soil or using complex methods of chemical stabilization. The clay of medium to high compressibility characterized by high swelling and shrinkage properties which covers the area of west Maharashtra regions has become a challenge to the engineers in construction. This soil when becomes dry is very hard but loses its strength properties completely when it is in wet condition. Therefore, it is very important to know various properties of soil such as physical and engineering properties. Soil can be stabilized by chemically or mechanically. The chemical stabilizers are the substances that can enter in the natural reactions of the soil and control the moisture which is getting into the clay particle. We all know that red soil 


\section{International Journal of Innovations in Engineering and Science, www.ijies.net}

has slow swelling and shrinkage properties, and high load bearing properties also. So, to stabilized black cotton soil here we use red soil to overcome properties of black cotton soil and to increase the bearing capacity of soil.

\section{II-METHOLOGY}

In this comparative study we performed Sieve analysis, Liquid limit, Plastic limit, Free swell index, Light compaction test, and light compaction with different proportion of soil mix. After performing all the above test for Black cotton soil and Red soil, we got the results which are shown in following table.

1. Black cotton soil

Table 1-Properties of Black cotton soil.

\begin{tabular}{|c|c|c|}
\hline Sr.no & Properties & Content \\
\hline 1 & Grain size distribution & \\
& D10 & $0.0017 \mathrm{~mm}$ \\
& D30 & $0.0045 \mathrm{~mm}$ \\
& D60 & \\
& & 11.76 \\
& $(\mathrm{Cc})$ & 0.60 \\
\hline 2 & $(\mathrm{Cu})$ & $47.1 \%$ \\
\hline 3 & Liquid limit & $12.8 \%$ \\
\hline 4 & Plastic limit & $34.3 \%$ \\
\hline 5 & Plasticity index & $20 \%$ \\
\hline 6 & Swelling index & $1.397 \mathrm{gm} / \mathrm{cc}$ \\
\hline 7 & Maximum dry density & 29 \\
\hline 8 & Optimum moisture & \\
\hline
\end{tabular}

2. Red soil

Table 2 -Properties of red soil

\begin{tabular}{|c|c|c|}
\hline Sr.no & Properties & Content \\
\hline & Grain size distribution & \\
1 & D10 & $0.0018 \mathrm{~mm}$ \\
& D30 & $0.0045 \mathrm{~mm}$ \\
& D60 & $0.03 \mathrm{~mm}$ \\
\hline \multirow{2}{*}{2} & $(\mathrm{Cc})$ & 16.67 \\
& $(\mathrm{Cu})$ & 0.38 \\
\hline 3 & Liquid limit & $51 \%$ \\
\hline 4 & Plastic limit & $15.44 \%$ \\
\hline 5 & Plasticity index & $35.56 \%$ \\
\hline 6 & Swelling index & $20 \%$ \\
\hline 7 & Maximum dry density & $1.42 \mathrm{gm} / \mathrm{cc}$ \\
\hline 8 & Optimum moisture content & $26 \%$ \\
\hline
\end{tabular}

The results of Light compaction with different proportions are given below,

Table 3 -Compaction test result

\begin{tabular}{|c|c|c|c|}
\hline \multicolumn{2}{|c|}{ Proportion } & \multirow{2}{*}{$\begin{array}{c}\text { MDD } \\
(\mathbf{g m} / \mathbf{c c})\end{array}$} & $\begin{array}{c}\text { OMC } \\
(\%)\end{array}$ \\
\cline { 1 - 2 } $\begin{array}{c}\text { BC soil } \\
(\%)\end{array}$ & $\begin{array}{c}\text { Red soil } \\
(\%)\end{array}$ & 1.427 & 31 \\
\hline 20 & 80 & 1.357 & 33.9 \\
\hline 30 & 70 & 1.314 & 34.9 \\
\hline 40 & 60 & 1.348 & 34.2 \\
\hline 50 & 50 & 1.371 & 30.3 \\
\hline 60 & 40 & 1.398 & 29.7 \\
\hline 70 & 30 & 1.415 & 27.6 \\
\hline 80 & 20 & & \\
\hline
\end{tabular}

From above we got a highest MDD i.e., $1.427 \mathrm{gm} / \mathrm{cc}$ and the corresponding proportion is $20 \%$ of $\mathrm{BC}$ soil and $80 \%$ of red soil.

Percentage increase in MDD

Table 4 -Percentage increase in MDD

\begin{tabular}{|c|c|c|}
\hline \multicolumn{2}{|c|}{$\%$ Increment for different soil } & \% Increased \\
\hline MDD of BC soil & $1.397 \mathrm{gm} / \mathrm{cc}$ & $2.15 \%$ \\
\hline MDD of Red soil & $1.420 \mathrm{gm} / \mathrm{cc}$ & $0.49 \%$ \\
\hline $\begin{array}{c}\text { MDD of mixed } \\
\text { proportion }\end{array}$ & $1.427 / \mathrm{cc}$ & \\
\hline
\end{tabular}

III- CONCLUSION

Earlier studies were mainly concentrated on different types of soil like BC soil, Laterite soil and only some studies were conducted on sandy soil. In the previous work the black cotton soil is mixed with red soil to find out suitable blend and to overcome drawbacks of black cotton soil.

From the current revision, the subsequent conclusions can be made.

- According to the sieve analysis the black cotton soil and red soil are found as fined grained soil.

- To understand the flow characteristic of soil Liquid limit and plastic limit tests are done, and found as $47.1 \%$ and $12.8 \%$ for BC soil and 51.5 $\%$ and $15.5 \%$ and also the plasticity index for respective soil is $34.1 \%$ and $36.5 \%$.

- The free swell index of both BC soil and red soil are found as $20 \%$ and $30 \%$. 


\section{International Journal of Innovations in Engineering and Science, www.ijies.net}

- According to the standard proctor test the Maximum Dry Density and Optimum Moisture Content for black cotton soil and red soil are found as $1.397 \mathrm{gm} / \mathrm{cc} \& 23 \%$ and $1.42 \mathrm{gm} / \mathrm{cc}$ and $26 \%$.

- Black cotton soil is mixed with red soil and the suitable blend is found out, which increases MMD of BC soil and red soil by $2.147 \%$ and $0.49 \%$ respectively.

\section{ACKNOWLEDGMENT}

The authors are grateful to the Principal, St. John College of Engineering and Management, Palghar, Maharashtra India for encouragement and granting permission for this project and also to publish this project. Authors acknowledge the support received from the department and well-wishers.

\section{REFERENCES}

[1] Priyanka M Shakal, Surekha M Shaka2. (2016) on Laboratory investigation on black soil and red soil using enzyme.

[2] A. U. Ravi Shankarl, Amulya. S2 \& Jogineni Ganesh (February 2018) on Experimental investigation on lateritic and black soil with bio enzyme.

[3] Nawab sharif Risaldarl, Prof M. S. Rajashekhar2, Mahejabeen Patel (July, 2017) on Stabilization of black soil with red mud and formulation of linear Regression between properties of the mixes.

[4] P. IMRAN KHAN, Mrs. M.KALPANA (2018) review on experimental study on stabilization of black soil using stone dust

[5] Shailendra Singh, Hemant B. Vasaikar, (June, 2015) on Stabilization of black cotton soil using lime.

[6] Department of civil engineering, A laboratory manual / journal for Geotechnical Engineering-1.

[7] Soil mechanics and foundation by B. C. Punmia.

[8] Soil mechanics andfoundation engineering by $\mathrm{Dr}$ K.R. Arora

[9] IS-2720 (part-4) 1980, IS-2720 (part-5) 1958, IS-2720 (part-5) 1985, IS-2720 (part-11) 1977, IS-2720 (part-7) 1980 